\title{
Bay breeze influence on surface ozone at Edgewood, MD during July 2011
}

\author{
Ryan M. Stauffer • Anne M. Thompson • \\ Douglas K. Martins • Richard D. Clark • \\ Daniel L. Goldberg • Christopher P. Loughner • \\ Ruben Delgado • Russell R. Dickerson • \\ Jeffrey W. Stehr • Maria A. Tzortziou
}

Received: 13 July 2012 / Accepted: 29 October 2012/

Published online: 16 November 2012

(C) The Author(s) 2012. This article is published with open access at Springerlink.com

\begin{abstract}
Surface ozone $\left(\mathrm{O}_{3}\right)$ was analyzed to investigate the role of the bay breeze on air quality at two locations in Edgewood, Maryland (lat: $39.4^{\circ}$, lon: $-76.3^{\circ}$ ) for the month of July 2011. Measurements were taken as part of the first year of NASA's "Deriving Information on Surface Conditions from Column and Vertically Resolved Observations Relevant to Air Quality" (DISCOVER-AQ) Earth Venture campaign and as part of NASA's Geostationary for Coastal and Air Pollution Events Chesapeake Bay Oceanographic campaign with DISCOVER-AQ (Geo-CAPE CBODAQ). Geo-CAPE CBODAQ complements DISCOVER-AQ by providing ship-based observations over the Chesapeake Bay. A major goal of DISCOVER-AQ is determining the relative roles of sources, photochemistry and local meteorology during air quality events in the Mid-Atlantic region of the U.S. Surface characteristics, transport and vertical structures of $\mathrm{O}_{3}$ during bay breezes were identified using in-situ surface, balloon and aircraft data, along with remote sensing equipment. Localized late day peaks in $\mathrm{O}_{3}$ were observed during bay breeze days, maximizing an average of $3 \mathrm{~h}$ later
\end{abstract}

R. M. Stauffer $(\bowtie) \cdot$ A. M. Thompson • D. K. Martins

Department of Meteorology, The Pennsylvania State University, University Park, PA 16802, USA

e-mail: rms5539@psu.edu

R. D. Clark

Department of Earth Sciences, Millersville University, Millersville, PA 17551, USA

D. L. Goldberg • R. R. Dickerson • J. W. Stehr

Department of Atmospheric and Ocean Science, University of Maryland, College Park, MD 20742, USA

C. P. Loughner • M. A. Tzortziou

Earth System Science Interdisciplinary Center, University of Maryland, College Park, MD 20742, USA

C. P. Loughner • M. A. Tzortziou

NASA Goddard Space Flight Center, Greenbelt, MD 20771, USA

R. Delgado

Joint Center of Earth Systems Technology, University of Maryland-Baltimore County, Baltimore, MD 21250, USA 
compared to days without bay breezes. Of the 10 days of July 2011 that violated the U.S. Environmental Protection Agency (EPA) $8 \mathrm{~h} \mathrm{O}_{3}$ standard of 75 parts per billion by volume (ppbv) at Edgewood, eight exhibited evidence of a bay breeze circulation. The results indicate that while bay breezes and the processes associated with them are not necessary to cause exceedances in this area, bay breezes exacerbate poor air quality that sustains into the late evening hours at Edgewood. The vertical and horizontal distributions of $\mathrm{O}_{3}$ from the coastal Edgewood area to the bay also show large gradients that are often determined by boundary layer stability. Thus, developing air quality models that can sufficiently resolve these dynamics and associated chemistry, along with more consistent monitoring of $\mathrm{O}_{3}$ and meteorology on and along the complex coastline of Chesapeake Bay must be a high priority.

Keywords Ozone $\cdot$ Bay Breeze $\cdot$ Pollution $\cdot$ Edgewood $\cdot$ Mid-Atlantic $\cdot$ DISCOVER-AQ

\section{Introduction}

\subsection{Surface ozone regulation}

Surface ozone $\left(\mathrm{O}_{3}\right)$ is a secondary photochemical pollutant formed from a number of reactions involving volatile organic compounds (VOCs), nitrogen oxides $\left(\mathrm{NO}_{\mathrm{x}} \equiv \mathrm{NO}+\mathrm{NO}_{2}\right)$ and sunlight. Ozone production and surface mixing ratios are also dependent on a complex combination of meteorological processes including incoming solar radiation, temperature, humidity, boundary layer height, and surface wind speed (Comrie 1990; Sillman and Samson 1995; Bloomer et al. 2009; Steiner et al. 2010; Banta et al. 2011). The ability of $\mathrm{O}_{3}$ to negatively affect respiratory systems in humans and vegetation photosynthesis (Krupa and Manning 1988; Burnett et al. 1994; Jerrett et al. 2009) has led the U.S. Environmental Protection Agency (EPA) to adopt $\mathrm{O}_{3}$ as a criteria pollutant. Ozone is regulated by the current standard of 75 parts per billion by volume (ppbv), calculated using the daily maximum of an $8 \mathrm{~h}$ running mean (National Ambient Air Quality Standards or NAAQS, EPA).

\subsection{Bay breeze association with coastal air quality}

Coastal areas near urban centers are often subjected to poor air quality through either direct downwind transport of pollutants (Angevine et al. 2004), in-situ production of $\mathrm{O}_{3}$, or a recirculation brought about by a bay or sea breeze (Banta et al. 2005). Bay or sea breeze (bay breeze from hereon) circulations and their association with poor air quality have been extensively studied in various locations throughout the world (Gangoiti et al. 2002; Darby 2005; Darby et al. 2007; Zhang et al. 2007; Rappenglück et al. 2008; Wu et al. 2010; Banta et al. 2011; Loughner et al. 2011; Martins et al. 2012). This study will focus on the impact of bay breezes on air quality in the northern Chesapeake Bay region in the Mid-Atlantic United States.

The meteorological conditions that are typically associated with the formation of bay breeze circulations also favor enhanced $\mathrm{O}_{3}$ production. Warm temperatures and strong sunlight accelerate the reactions that produce $\mathrm{O}_{3}$, and the calm or light winds necessary to allow the bay breeze to become dominant can lead to additional accumulation of $\mathrm{O}_{3}$ through reduced boundary layer venting and dispersion. Differential heating of the land and water leads to hydrostatic pressure gradients that force the movement of near-surface air from water to land during the day under relatively quiescent large-scale flow (Miller et al. 2003). As the land cools much faster than water at night, a reversal of the temperature and pressure 
gradients can cause flow in directions opposite the afternoon bay breeze. This aids in the early morning transport of emissions from over the land to over the bay waters. The $\mathrm{O}_{3}$ produced from these emissions is then recirculated back over coastal sites via the bay breeze (Wang et al. 2001; Ding et al. 2004).

In addition to comparable meteorological conditions favoring both bay breeze initiation and $\mathrm{O}_{3}$ production, differences in the air masses and behavior of $\mathrm{O}_{3}$ between land and water surfaces introduce further effects. Mixing depths over water are typically lower than those found over land during the daytime due to water having a much higher heat capacity compared to land (Hsu and Blanchard 2003). When the stable over-water air mass is advected onto land, the mixing height is typically determined by the height of the Thermal Internal Boundary Layer when formed (TIBL; Raynor et al. 1979). TIBLs form when the stable air mass modified by its passage over a water body contacts the land surface and forms separate layers of stability within the terrestrial boundary layer. TIBLs are frequently much shallower than the terrestrial boundary layer. Through reduced mixing, this shallow, more statically stable zone concentrates pollutants that continue to be emitted from the terrestrial surfaces. Mixing depths in coastal areas of the Mid-Atlantic and Chesapeake Bay region have been shown to decrease significantly from inland sites (Berman et al. 1999), often attributed to bay or sea breeze effects. The pollutants concentrated in these shallow, stable layers are then trapped and transported inland via the bay breeze (Banta et al. 2005).

Further aiding the build-up of $\mathrm{O}_{3}$, characteristic deposition velocities of $\mathrm{O}_{3}$ over water are six times smaller than those over land $\left(\sim 0.07 \mathrm{~cm} \mathrm{~s}^{-1}\right.$ vs. $\sim 0.4 \mathrm{cms}^{-1}$ respectively; Lenschow et al. 1981; Lenschow et al. 1982; Hauglustaine et al. 1994; Wesely and Hicks 2000), yielding minimal $\mathrm{O}_{3}$ loss onto a water surface compared to a land surface through deposition. Compounding these factors with ideal meteorological conditions leads to the accumulation of high $\mathrm{O}_{3}$ mixing ratios and advection to nearby coastal locations.

This study uses numerous instruments from the July 2011 DISCOVER-AQ and GeoCAPE CBODAQ deployments to investigate the bay breeze phenomenon. The goals are to examine the spatial and temporal evolution of $\mathrm{O}_{3}$ as it is affected by the bay breeze, as well as the vertical structure of $\mathrm{O}_{3}$ and atmospheric stability during these events.

\section{Methods}

Table 1 summarizes the measurements utilized in this study.

\subsection{Edgewood, Maryland}

The $\mathrm{O}_{3}$ design value, defined as the 3-year average of the fourth highest annual 8-h maximum $\mathrm{O}_{3}$ mixing ratio, determines compliance with the EPA NAAQS. In the Baltimore Non-Attainment Area (NAA; Maryland Department of the Environment), the highest $\mathrm{O}_{3}$ design value is consistently observed in Edgewood. In fact, Edgewood is the only monitor within its EPA Ozone Transport Region (OTR), an area stretching from Virginia to Massachusetts, that currently breaches the previous NAAQS of 84 ppbv enacted in 1997. Edgewood is also often the lone monitor in the Baltimore NAA to exceed the $75 \mathrm{ppbv}$ standard on particular days (Landry 2011). It is believed that the bay breeze plays a major role in the exceptionally poor air quality at Edgewood (Piety 2007).

Air quality measurements for DISCOVER-AQ (http://www.nasa.gov/discover-aq) 2011 were collected during the month of July at several pre-existing Maryland Department of the Environment (MDE) locations in the Baltimore-Washington Metropolitan Area (Fig. 1). 
Table 1 Measurements utilized in this study with uncertainties/accuracies and the platforms on which they were deployed

\begin{tabular}{|c|c|c|c|}
\hline Instrument, Model & Platform & Measurement & Uncertainty/Accuracy \\
\hline TECO Inc., 49C & NATIVE & Surface $\mathrm{O}_{3}$ & $\pm 2 \%$ \\
\hline TECO Inc., 42C-Y & NATIVE & $\mathrm{NO} / \mathrm{NO}_{\mathrm{y}}$ & $\pm 3 \%$ \\
\hline RM Young, \#05103 & NATIVE & Wind Speed, Direction & $\pm 0.3 \mathrm{~m} / \mathrm{s}, \pm 3^{\circ}$ \\
\hline RM Young, \#41382 & MDE Trailer & Temperature, $\mathrm{RH}$ & $\pm 0.3{ }^{\circ} \mathrm{C}, \pm 1 \%\left(\right.$ at $\left.23{ }^{\circ} \mathrm{C}\right)$ \\
\hline ENSCI Corp., Model 2Z & Free Balloon & Ozone & $<10 \%$ \\
\hline Intermet, iMet-1 & Free Balloon & Temperature, RH, Pressure & $\begin{array}{l} \pm 0.3^{\circ} \mathrm{C}, \pm 5 \%, \pm 1.8 \mathrm{hPa} \\
\quad(400-1070 \mathrm{hPa}), \pm 0.5 \mathrm{hPa} \\
(4-400 \mathrm{hPa})\end{array}$ \\
\hline Sigma Space, Mini-MPL & NATIVE & Backscattered $532 \mathrm{~nm}$ & $\pm 2 \%$ for all altitudes \\
\hline Teledyne, 400A & MABL & Surface $\mathrm{O}_{3}$ & $\pm 2 \%$ \\
\hline ScinTec, windRASS & MABL & $\begin{array}{l}\text { Vertically Resolved Wind } \\
\text { Speed, Direction }\end{array}$ & $\begin{array}{l}0.3-0.5 \mathrm{~m} / \mathrm{s},<1.5^{\circ} \\
\quad(\text { at }<2.0 \mathrm{~m} / \mathrm{s})\end{array}$ \\
\hline Vaisala, TTS111 & Tether Balloon & Temperature, RH, Pressure & $\pm 0.5^{\circ} \mathrm{C}, \pm 5 \%, \pm 1.5 \mathrm{hPa}$ \\
\hline 2B-Technologies, 205 & Tether Balloon & Ozone & $\pm 2 \%$ \\
\hline $\begin{array}{l}\text { NCAR } 4 \text { Channel } \\
\text { Chemiluminescence }\end{array}$ & P3-B & Ozone & $\pm 5 \%$ \\
\hline General Eastern, 1011B & P3-B & Temperature & $\pm 0.2^{\circ} \mathrm{C}$ \\
\hline Rosemount, 102 & P3-B & Dew/Frost Point & $\pm 0.6^{\circ} \mathrm{C}$ \\
\hline Rosemount, MADT 2014 & P3-B & Pressure & $\pm 0.25 \mathrm{hPa}$ \\
\hline TECO Inc., 49C & Cessna 402B & Ozone & \pm 1.0 ppbv (estimated) \\
\hline Vaisala, PTU 300 & Cessna 402B & Temperature, RH, Pressure & $\begin{array}{l} \pm 0.2{ }^{\circ} \mathrm{C}, \pm 1 \%, \pm 0.2 \mathrm{hPa} \\
\quad\left(\text { at } 20{ }^{\circ} \mathrm{C}\right)\end{array}$ \\
\hline TECO Inc., 49 & NOAA SRVx & Surface $\mathrm{O}_{3}$ & $\pm 5 \%$ (estimated) \\
\hline
\end{tabular}

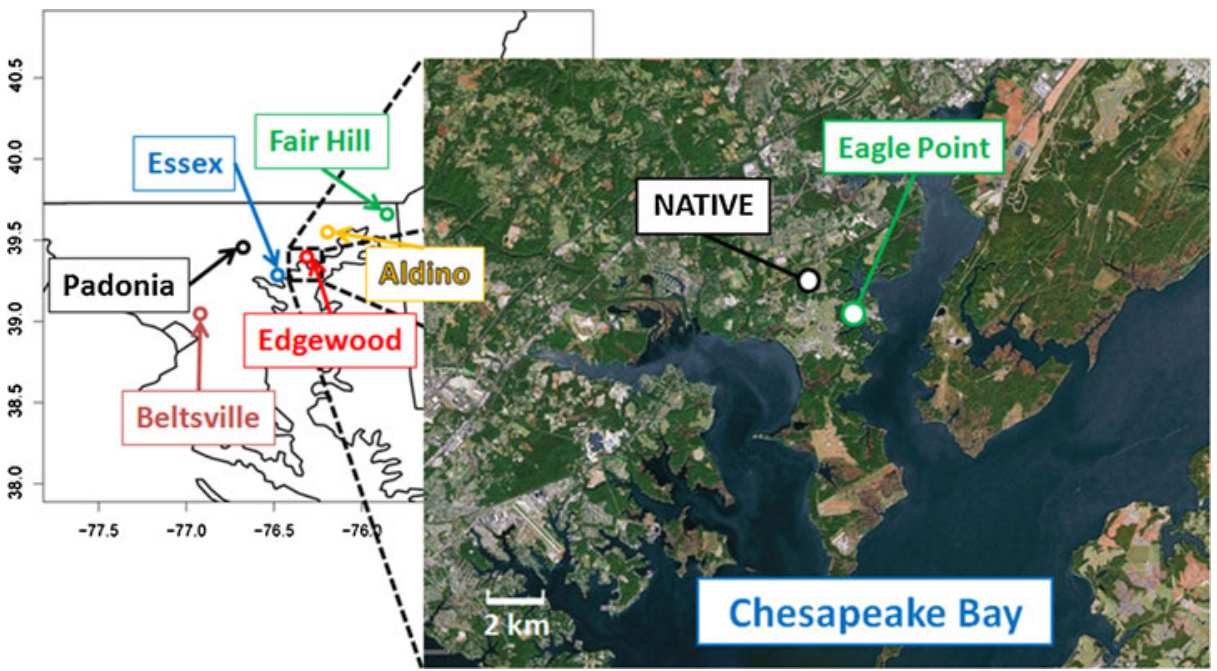

Fig. 1 Map of the DISCOVER-AQ ground sites used in this study. All sites are located in Maryland. Edgewood area is expanded to show relative locations of NATIVE and Eagle Point to the Chesapeake Bay 
Ship measurements of air quality in the upper Chesapeake Bay were collected during 11-20 July 2011 as part of NASA's oceanographic campaign Geo-CAPE CBODAQ (http://neptu ne.gsfc.nasa.gov/osb/index.php?section=250). Much of the results presented in this manuscript are from measurements collected at the Edgewood side of the Aberdeen Proving Ground (APG), in Aberdeen and Edgewood. APG is a U.S. Army facility with a population of just over 3,000 on site. Aberdeen and Edgewood proper have populations of approximately 15,000 and 25,000 respectively, but are often influenced chemically by transport of $\mathrm{NO}_{\mathrm{x}}$ and VOC emissions from the greater Baltimore-Washington Metropolitan Area, a Combined Statistical Area, or grouping of metropolitan areas, with 9 million residents. It is noted that the recent transfer of 50,000 people or more due to the Defense Base Realignment and Closure (BRAC) program is expected to add to the local population (Fry, http://articles.centermaryland.org). Thus, this study provides important baseline air quality information for the Edgewood area.

\subsection{Edgewood mobile trailer measurements}

The Nittany Atmospheric Trailer and Integrated Validation Experiment (NATIVE; lat: $39.410^{\circ}$, lon: $-76.297^{\circ}$; see Martins et al. 2012 for full description), a mobile platform designed for atmospheric process studies and comparison of satellite, air quality and groundbased measurements, provided 1 min averaged in-situ chemical measurements at Edgewood, including $\mathrm{O}_{3}, \mathrm{NO} / \mathrm{NO}_{2} / \mathrm{NO}_{\mathrm{x}}$, total reactive nitrogen $\left(\mathrm{NO}_{\mathrm{y}}\right)$, sulfur dioxide $\left(\mathrm{SO}_{2}\right)$ and carbon monoxide $(\mathrm{CO})$. Instruments for measuring atmospheric pressure, wind speed/direction, $\mathrm{NO}_{2}$ photolysis rates and UV radiation were also part of the NATIVE payload. Temperature and relative humidity were measured on a MDE trailer (FIPS Code: 240251001) located approximately $10 \mathrm{~m}$ from NATIVE.

Free-flying ozonesondes were also launched from the NATIVE site at Edgewood. The ozonesondes used the Electrochemical Concentration Cell (ECC; Komhyr 1969) technique. Ozonesondes were launched with an attached radiosonde (International Met Systems; iMet-1) equipped with temperature, humidity and pressure sensors. Ozonesondes were either launched twice a day to correspond with NASA P3-B aircraft spirals on flight days, or once daily to coincide with the Aura satellite overpass at approximately 1330 Eastern Standard Time (EST; all times presented are in EST due to the photochemical nature of $\mathrm{O}_{3}$ production).

Additional instruments were added to the NATIVE platform for the 2011 DISCOVERAQ campaign. Sigma Space Mini Micropulse Lidar (MiniMPL) provided elastic lidar observations at Edgewood. The MiniMPL lidar transmitter consists of a $532 \mathrm{~nm}$ (frequency-doubled Nd: YAG laser) that operates at a 5,000 Hz repetition rate and average pulse energy of 3-4 $\mu \mathrm{J}$. The receiver consists of an $80 \mathrm{~mm}$ telescope that collects co-polarized backscattered light. The output from the telescope is conveyed to a photon counting silicon avalanche photo-diode (APD) manufactured by Perkin-Elmer. The raw data is converted to aerosol attenuated backscatter by taking into account instrumental factors that include corrections for detector dead time, geometrical overlap, background subtraction, and range-squared normalization. Recorded lidar profiles have temporal and vertical resolution of $1 \mathrm{~min}$ and $30 \mathrm{~m}$, respectively.

The MPL lidar is a powerful tool for visualizing, in real time, with high temporal and spatial resolution, the planetary boundary layer (PBL). The PBL contains greater aerosol concentration than the above free troposphere because the aerosols, mainly produced near the surface, are trapped by a potential temperature inversion. The backscatter signal strength is dramatically reduced when returning from the free troposphere. A covariance wavelet technique (CWT) was applied to the lidar signal to determine the height of these gradients in 
the backscatter profiles. These heights were used as a proxy for the height of the PBL (Davis et al. 2000; Brooks 2003).

\subsection{Eagle Point Edgewood measurements}

The Millersville University Atmospheric Boundary Layer (MABL) facility was deployed to Eagle Point, APG approximately $2.7 \mathrm{~km} \mathrm{SE}$ of NATIVE (Fig. 1; lat: 39.396 ${ }^{\circ}$, lon: $-76.269^{\circ}$ ) to provide surface and boundary layer observations in support of DISCOVER-AQ. MABL is an integrated multi-platform facility that includes surface trace gas analyzers and particle scattering instrumentation, a $4 \mathrm{~m}$ tower for measuring surface fluxes, MPL, and an acoustic sodar with radio acoustic sounding extension. These surface instruments integrate with aloft measurements obtained using a tethered aerostat, rigged to carry meteorological and air quality monitoring instrumentation. Trace gas concentrations were measured using a suite of Teledyne API analyzers; $\mathrm{O}_{3}$ Model 400A, NO/NO $2 / \mathrm{NO}_{\mathrm{X}}$ Model 200A, $\mathrm{SO}_{2}$ Model 100A, and $\mathrm{CO}$ Model 300A, and sampled from the manifold at their respective specified volumetric flow rates at atmospheric pressure. Methods are identical to those of NATIVE for these gases. The response and concentration of each instrument was monitored at least weekly using the NATIVE multigas calibration system. A ScinTec Acoustic Sodar windRASS was used to produce time-height series of $\mathrm{u}, \mathrm{v}, \mathrm{w}$ wind components and virtual temperature. Selftests were conducted daily on the sodar to assure within-spec operation. The tethered aerostat was used to carry aloft meteorological sensors, which measured temperature, pressure, relative humidity, wind speed and wind direction using a Vaisala TTS111 tethersonde. In addition, the aerostat deployed 2B-Technologies Inc. trace gas analyzers for profiles of $\mathrm{O}_{3}, \mathrm{NO}$, and $\mathrm{NO}_{\mathrm{x}}$. Daily comparisons were made with surface analyzers. The 2Btech Model 205 measures $\mathrm{O}_{3}$ using UV absorption at $254 \mathrm{~nm}$ every $2 \mathrm{~s}$ and the measurements were averaged to $5 \mathrm{~min}$ to conform to the $\mathrm{NO} / \mathrm{NO}_{\mathrm{X}}$ sampling rate. The Model 205 has a baseline drift of $<1 \mathrm{ppbv}$ day ${ }^{-1}$; sensitivity drift of $<1 \%$ day $^{-1}$, and resolution of $0.1 \mathrm{ppbv}$. Uncertainty in $\mathrm{O}_{3}$ was $2 \%$. NO was obtained with a 2 Btech Model 410 and is based on a selective reaction with $\mathrm{O}_{3}$ and the resulting change in UV absorption from the $\mathrm{O}_{3}$ depletion. A Model 401 Molybdenum converter was used to obtain $\mathrm{NO}_{\mathrm{X}}$. Data were averaged to $5 \mathrm{~min}$ with uncertainty of $2 \%$.

\section{4 $\mathrm{MDE} \mathrm{O}_{3}$ measurements}

Additional $\mathrm{O}_{3}$ measurements were taken at existing MDE locations within the DISCOVERAQ domain at Aldino (FIPS Code: 240259001), Beltsville (240330030), Essex (240053001), Fair Hill (240150003), and Padonia (240051007), MD. In addition to Edgewood, these sites were the locations where NASA's P3-B collected vertical profile spirals during the campaign. Aldino, Beltsville, and Essex are equipped with Thermo Scientific 49i or 49C O $\mathrm{O}_{3}$ analyzers and Fair Hill and Padonia used Ecotech $9810 \mathrm{O}_{3}$ analyzers. All surface $\mathrm{O}_{3}$ instruments in this study employ a UV-Photometry method where mixing ratios are determined from UV extinction through a sample cell.

\subsection{Aircraft measurements}

NASA's P3-B and the University of Maryland's Cessna 402B aircraft were deployed during the DISCOVER-AQ campaign to obtain vertical profiles of air quality measurements over ground sites. The aircraft occasionally performed profile spirals and transects at low altitudes across the Chesapeake Bay. $\mathrm{O}_{3}$ measurements from the P3-B were made using the National 
Center for Atmospheric Research (NCAR) 4-Channel Chemiluminescence Instrument, where ambient $\mathrm{O}_{3}$ is reacted with excess $\mathrm{NO}$ to produce photons. The photons are then counted using a cooled photomultiplier tube (PMT) and converted into an $\mathrm{O}_{3}$ mixing ratio in $1 \mathrm{~s}$ averages with $5 \%$ uncertainty. The Cessna 402B employed a UV-Photometry method using a Thermo Scientific $49 \mathrm{C} \mathrm{O}_{3}$ analyzer to produce $10 \mathrm{~s}$ averaged $\mathrm{O}_{3}$ mixing ratios with an estimated 1 ppbv uncertainty.

\subsection{Ship measurements}

The NOAA SRVx National Marine Sanctuary Test and Evaluation Vessel sailed the Chesapeake Bay from 11 to 20 July as part of the Geo-CAPE CBODAQ field campaign. Air and water quality measurements were made onboard the ship, including in-situ $\mathrm{O}_{3}$ observations over the water surface. Ozone on SRVx was measured using UV-Photometry with a Thermo Scientific $49 \mathrm{O}_{3}$ analyzer averaged to $10 \mathrm{~s}$ with an estimated $5 \%$ uncertainty.

\subsection{Bay breeze identification}

Meteorological criteria were set specifically for the Edgewood site and evaluated for each day to determine if a bay breeze circulation occurred. These requirements were: (1) a daytime wind shift from calm or offshore (southwesterly to easterly directions, moving clockwise from $\sim 230^{\circ}$ to $090^{\circ}$ ) to onshore (easterly to southwesterly directions, moving clockwise from $\sim 100^{\circ}-220^{\circ}$ ), (2) an increase in dew point temperature of at least $1{ }^{\circ} \mathrm{C}$ within $1 \mathrm{~h}$ after onset of wind shift, and (3) the lack of a meso-or synoptic scale front analyzed by the Hydrometeorological Prediction Center (HPC; hpc.noaa.gov). A criterion involving a steadying or decreasing dry bulb temperature was considered as in Sikora et al. (2010), but failed to discriminate further between bay breeze days and non-bay breeze days, and was thus eliminated.

\section{Results}

\subsection{Bay breeze days}

Bay breezes were identified on 02, 05, 23, 26 and 29 July. Four additional days (07, 19, 22, and 31 July) exhibited evidence of bay breeze initiation that was then inhibited by clean midtropospheric air from a local thunderstorm gust front, or the thunderstorm itself. Such days are classified separately as "interrupted" days. An overview of surface $\mathrm{O}_{3}$ during the entire month of July 2011 at Edgewood is provided in Table 2. Color codes based on the EPA National Ambient Air Quality Standard (NAAQS) are presented. There were a total of ten exceedances (Code Orange or higher) of the EPA 8-h $\mathrm{O}_{3}$ standard of 75 ppbv at Edgewood during July 2011. Of these ten exceedances, eight occurred on either bay breeze days or "interrupted" days, with the only two Code Red days (defined as 96 to 115 ppbv 8-h average $\mathrm{O}_{3}$ ) on 02 and 22 July.

An example of the bay breeze's effect on surface $\mathrm{O}_{3}$, wind direction and speed, temperature and dew point is shown for 23 July in Fig. 2. The bay breeze front passed through the Edgewood site at approximately 1130 EST as the wind direction veered to southerly directions. The dew point increased by approximately $4{ }^{\circ} \mathrm{C}$ and the temperature plateaued at $34{ }^{\circ} \mathrm{C}$ with the frontal passage, a sign of the cooler and moister modified air mass originating over the water being advected over the land. The bay breeze appeared to have moved through Edgewood as a wedge, evidenced by the shift in wind and stagnation first 
Table 2 July 20118 and 1-h $\mathrm{O}_{3}$ maxima by day. 8-h Max boxes are color-coded according to the NAAQS

\begin{tabular}{|c|c|c|c|}
\hline \multicolumn{4}{|c|}{ Edqewood, MD July 2011 EPA NAAQS Color Codes } \\
\hline $0.60 \mathrm{ppbv}$ & 61.75 ppbv & 76-95 ppbv & 96.115 ppbv \\
\hline Date & $8 \mathrm{hr}$ Max (ppbv) & $1 \mathrm{hr}$ Max (ppbv) & Bay Breeze? \\
\hline 01 July 2011 & 73.8 & 83.2 & No \\
\hline 02 July 2011 & 96.4 & 107.3 & Yes \\
\hline 03 July 2011 & 73.0 & 82.8 & No \\
\hline 04 July 2011 & 50.3 & 55.9 & No \\
\hline 05 July 2011 & 89.5 & 105.1 & Yes \\
\hline 06 July 2011 & 75.0 & 99.3 & No \\
\hline 07 July 2011 & 86.8 & 96.7 & "Interrupted" \\
\hline 08 July 2011 & 54.5 & 58.0 & No \\
\hline 09 July 2011 & 61.5 & 72.3 & No \\
\hline 10 July 2011 & 68.9 & 74.7 & No \\
\hline 11 July 2011 & 64.5 & 75.4 & No \\
\hline 12 July 2011 & 63.8 & 67.6 & No \\
\hline 13 July 2011 & 52.5 & 57.9 & No \\
\hline 14 July 2011 & 51.5 & 56.5 & No \\
\hline 15 July 2011 & 65.8 & 79.3 & No \\
\hline 16 July 2011 & 54.2 & 64.7 & No \\
\hline 17 July 2011 & 52.9 & 60.9 & No \\
\hline 18 July 2011 & 83.6 & 109.3 & No \\
\hline 19 July 2011 & 76.1 & 107.8 & "Interrupted" \\
\hline 20 July 2011 & 75.6 & 78.9 & No \\
\hline 21 July 2011 & 72.8 & 84.8 & No \\
\hline 22 July 2011 & 102.1 & 128.6 & "Interrupted" \\
\hline 23 July 2011 & 93.7 & 113.4 & Yes \\
\hline 24 July 2011 & 65.8 & 68.0 & No \\
\hline 25 July 2011 & 60.2 & 72.6 & No \\
\hline 26 July 2011 & 73.7 & 82.9 & Yes \\
\hline 27 July 2011 & 53.0 & 58.0 & No \\
\hline 28 July 2011 & 70.6 & 79.3 & No \\
\hline 29 July 2011 & 82.6 & 99.0 & Yes \\
\hline 30 July 2011 & 60.5 & 65.0 & No \\
\hline 31 July 2011 & 78.7 & 101.1 & "Interrupted" \\
\hline
\end{tabular}

noticed at the surface, then with height as time progresses. This can be expected as temperature gradients closest to the surface are normally greater than those above, and the resulting forcing is also greater closer to the surface. Surface $\mathrm{O}_{3}$ increases throughout the day and finally peaks at $1830 \mathrm{EST}$, leading to an exceedance with an $8 \mathrm{~h}$ average of 94 ppbv $\mathrm{O}_{3}$. This late day peak in $\mathrm{O}_{3}$ (after 1700 EST) occurred on three of five bay breeze days at 
Fig. 223 July bay breeze effect on wind direction with height (a, colors), Edgewood surface $\mathrm{O}_{3}$ (a, black dots), wind speed with height (b, colors), surface temperature (b, black dots), and dew point (b, grey dots). Bay breeze frontal passage occurred at approximately 1130 EST (vertical dashed line)
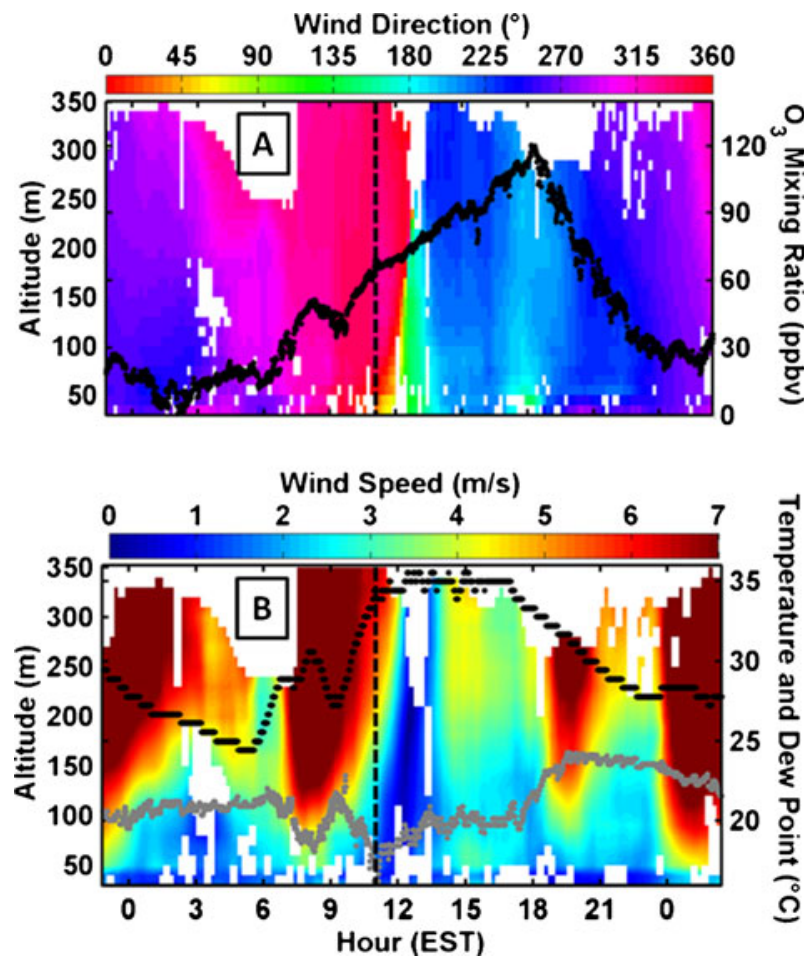

Edgewood and is notable because photochemical production of $\mathrm{O}_{3}$ at these hours should be well beyond its daily potential maximum.

Figure 3 compares the diurnal cycle of surface $\mathrm{O}_{3}$ at Edgewood over the five bay breeze days with the total range diurnal cycle of surface $\mathrm{O}_{3}$ for the 22 non-bay breeze days in July 2011. Data were binned into 20-min averages according to time of day. Four of the five bay

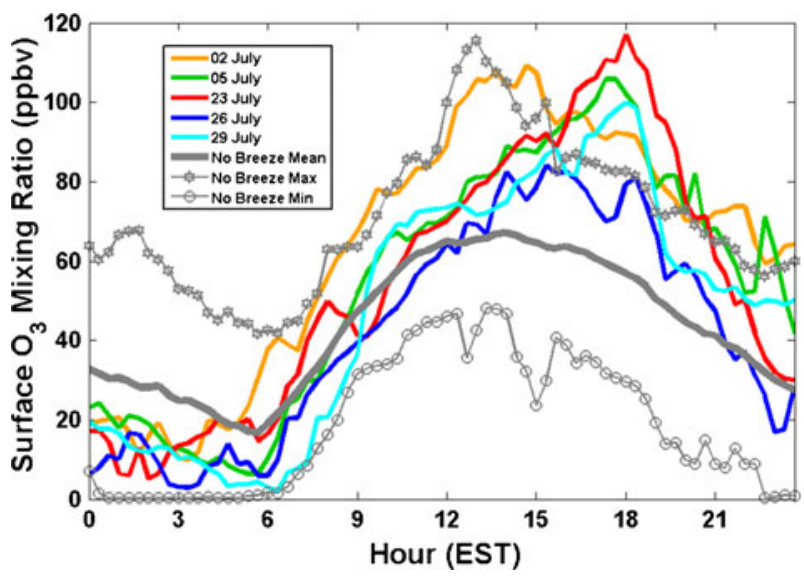

Fig. 3 Comparison of surface $\mathrm{O}_{3}$ on bay breeze days (colors) and non-bay breeze days (grey). Twenty minutes averages of $\mathrm{O}_{3}$ on each bay breeze day are shown against the minimum, mean, and maximum for every 20 min period of the day for all non-bay breeze days 
breeze days were observed to have higher $\mathrm{O}_{3}$ than any of the other 22 non-bay breeze days during the period of 1640 to 1900 EST. The maximum 1-h average $\mathrm{O}_{3}$ occurred approximately $3 \mathrm{~h}$ later for all 5 days as opposed to the 22 non-bay breeze days, which generally peaked in $\mathrm{O}_{3}$ around $1300-1400$ EST. The change in surface $\mathrm{O}_{3}$ for each day from 0800 to 1300 EST and from 1300 to 1800 EST shows that in both time periods, average accumulation rate of $\mathrm{O}_{3}$ on bay breeze days (0800-1300 EST: $8.1 \mathrm{ppbvhr}^{-1} ; 1300-1800$ EST: $\left.2.4 \mathrm{ppbvhr}^{-1}\right)$ is significantly greater than on non-bay breeze days $(0800-1300$ EST: 5.0 ppbvhr $^{-1} ; 1300-1800$ EST: -2.0 ppbvhr $^{-1}$ ) with $95 \%$ confidence. All confidence intervals were derived using a bootstrap sampling method with 10,000 iterations (Efron 1979; Efron and Tibshirani 1993).

\subsection{Chesapeake Bay measurements}

Boundary layer heights (BLHs) from P3-B spirals were determined from four different vertical potential $(\theta)$ and virtual potential $\left(\theta_{\mathrm{v}}\right)$ temperature gradient methods based on the work by Heffter (1980). The Heffter (1980) method can overestimate boundary layer and mixed layer heights (Berman et al. 1999), given that the $\theta$ inversion necessary to calculate these heights must be quite strong. With the possibility of moisture gradients and complex and weaker internal stable layers over the bay, $\theta_{\mathrm{v}}$ was also considered, which takes into account buoyancy added to an air parcel by water vapor. The inversion criteria were also modified slightly. The different boundary layer heights are estimated by the level closest to the surface having:

1) $\Delta \theta / \Delta \mathrm{z} \geq 5 \mathrm{~K} \mathrm{~km}^{-1}$ and $\theta_{\text {top }}-\theta_{\text {base }} \geq 2 \mathrm{~K}$; (Heffter 1980)

2) $\Delta \theta_{\mathrm{v}} / \Delta \mathrm{z} \geq 5 \mathrm{~K} \mathrm{~km}^{-1}$ and $\theta_{\text {vtop }}-\theta_{\text {vbase }} \geq 2 \mathrm{~K}$

3) $\Delta \theta_{\mathrm{v}} / \Delta \mathrm{z} \geq 5 \mathrm{~K} \mathrm{~km}^{-1}$ and $\theta_{\text {vtop }}-\theta_{\text {vbase }} \geq 1 \mathrm{~K}$

4) $\Delta \theta_{\mathrm{v}} / \Delta \mathrm{z} \geq 2 \mathrm{~K} \mathrm{~km}^{-1}$ and $\theta_{\text {vtop }}-\theta_{\text {vbase }} \geq 1 \mathrm{~K}$

where $\Delta \theta / \Delta \mathrm{z}$ is the potential (1) or virtual potential (2-4) temperature lapse rate and $\theta_{\text {top }}$ and $\theta_{\text {base }}$ is the potential or virtual potential temperature at the top and bottom of a layer. Only profiles over the bay that reached a minimum altitude of $400 \mathrm{~m}$ were considered. PBL heights were obtained from four to six P3-B spirals depending on the method used (spirals typically started at $\sim 3 \mathrm{~km}$, leading some methods to fail to mark a BLH), over the Chesapeake Bay and compared to coincident half hour averaged MPL-derived PBL heights at Edgewood to examine possible differences in mixing heights over land and water. Methods 1 and 2, both which were able to pick out four boundary layer heights from P3-B spirals, did not statistically differ from the MPL-derived boundary layer heights at Edgewood and had average absolute differences of $22.2 \%$ and $16.8 \%$, respectively. Methods 3 (five profile BLHs) and 4 (six profile BLHs) were both statistically different from MPL boundary layer heights to $95 \%$ confidence, and were lower by averages of $35.3 \%$ and $58.4 \%$ respectively.

The two weaker $\theta_{\mathrm{v}}$ criteria, methods 3 and 4, were required to calculate a mixed layer height from a P3-B profile from 26 July, a bay breeze day. A $1 \mathrm{~K}$ inversion in $\theta_{\mathrm{v}}$ from $640 \mathrm{~m}$ to $520 \mathrm{~m}$ was enough to trap $\mathrm{O}_{3}$ near the surface with 43 ppbv measured at $600 \mathrm{~m}$ and $73 \mathrm{ppbv}$ measured at $300 \mathrm{~m}$. In addition, a P3-B profile from 11 July over the Chesapeake revealed a decrease in $\theta_{\mathrm{v}}$ of $0.5 \mathrm{~K}$ from $300 \mathrm{~m}$ to $250 \mathrm{~m}$, with a corresponding increase in $\mathrm{O}_{3}$ of $63 \mathrm{ppbv}$ to $72 \mathrm{ppbv}$ near the surface. None of the four methods for determining boundary layer heights marked this shallow and weak inversion on 11 July. Several weaker stable layers often exist within the first few kilometers that can trap high $\mathrm{O}_{3}$ near the bay water surface. 
While the heights at which the strong inversion required by Heffter (1980) were marked matched well with the MPL-derived BLHs at Edgewood, the shallower and weaker inversions picked out by methods 3 and 4 can be enough to trap near-surface $\mathrm{O}_{3}$ over water and highlight the potential differences between mixing heights at coastal areas and over water surfaces as well as potential issues with MPL BLH determination methods in coastal areas.

Figure 4 presents three separate occasions when large land to water $\mathrm{O}_{3}$ gradients were observed. The Cessna 402B and P3-B performed transects of the Chesapeake on 07 and 29 July, respectively (Fig. 4b, c). On 07 July, an "interrupted" day, the Cessna observed an $\mathrm{O}_{3}$ increase from 88 ppbv to 114 ppbv as it descended from $290 \mathrm{~m}$ over land to $60 \mathrm{~m}$ over the bay at $1400 \mathrm{EST}$. On 29 July, a bay breeze day, the P3-B observed an increase in $\mathrm{O}_{3}$ from $80 \mathrm{ppbv}$ to $96 \mathrm{ppbv}$ as it descended from $380 \mathrm{~m}$ over land to $270 \mathrm{~m}$ over the water at $1445 \mathrm{EST}$.

The SRVx collected measurements in the Chesapeake Bay approximately $25 \mathrm{~km}$ south of Edgewood (Fig. $4 \mathrm{a} ; 39.170^{\circ},-76.325^{\circ}$ ) from 0730 to 1700 EST on 20 July. A sharp gradient in $\mathrm{O}_{3}$ of 15.4 ppbv averaged from the hours of 1500-1800 EST is observed over this short
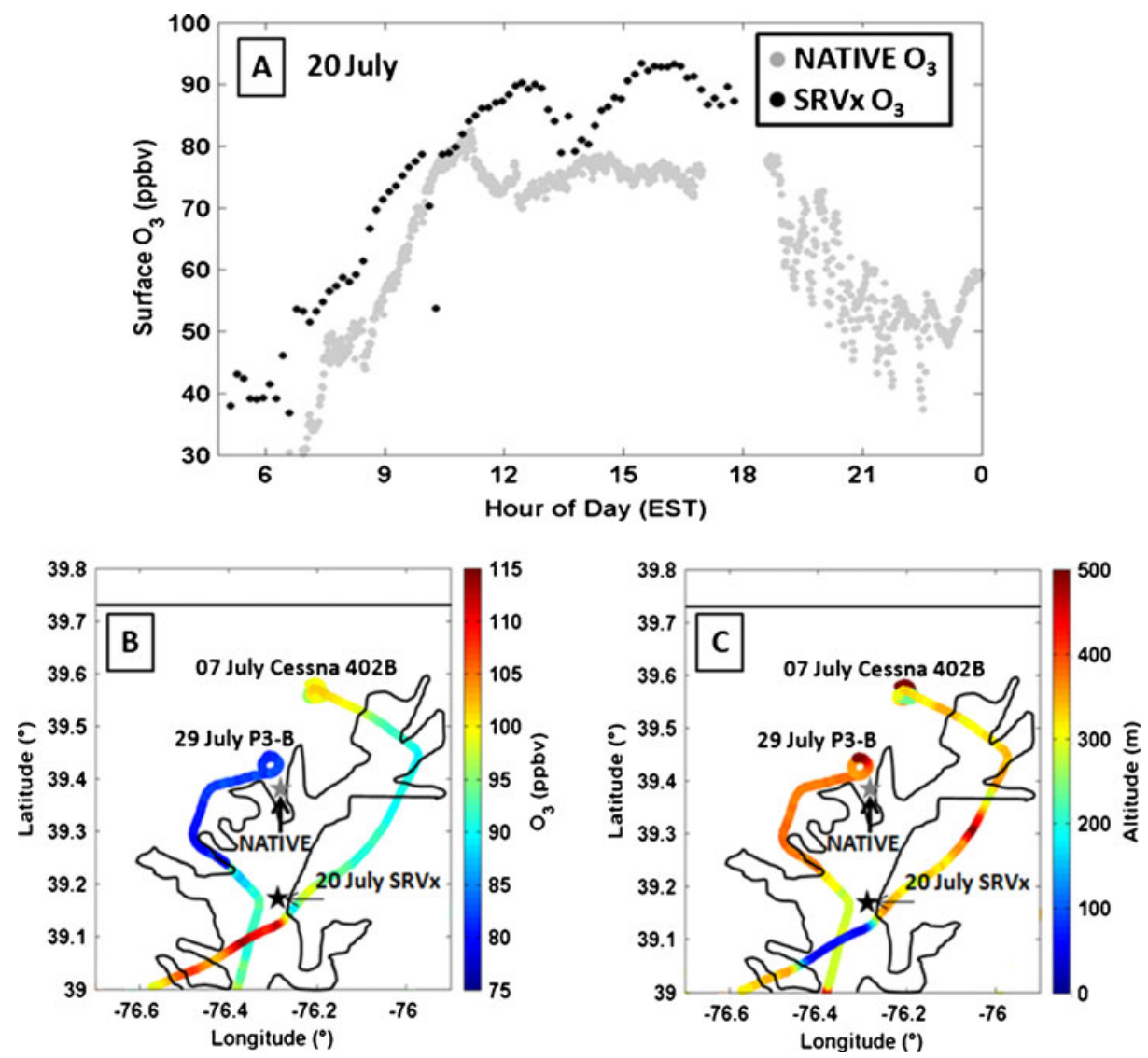

Fig. 4 Surface $\mathrm{O}_{3}$ on the $\mathrm{SRVx}$ (a, black dots, averaged to $10 \mathrm{~min}$ ) and at NATIVE (a, grey dots), $\mathrm{O}_{3}$ from the NASA P3-B and UMD Cessna 402B (b, colors) and flight altitude (c, colors) for three different days. SRVx surface $\mathrm{O}_{3}$ (a) was taken on 20 July and flights $(\mathbf{b}, \mathbf{c})$ are 07 July for the UMD Cessna, and 29 July for the NASA P3-B. Downward spikes in $\mathrm{SRVx} \mathrm{O}_{3}$ measurements are likely $\mathrm{O}_{3}$ titration in fresh $\mathrm{NO}$ plumes from the ship's engine exhaust 
distance from the Edgewood site to the ship. High surface $\mathrm{O}_{3}$ and large vertical gradients were also observed between the SRVx and the Cessna 402B on 20 July. The SRVx and Cessna measured $\mathrm{O}_{3}$ mixing ratio gradients of $16 \mathrm{ppbv}$ between the surface and $600 \mathrm{~m}$ at 1230 EST, $10 \mathrm{ppbv}$ between the surface and $300 \mathrm{~m}$ at $1500 \mathrm{EST}$, and $17 \mathrm{ppbv}$ from the surface to $300 \mathrm{~m}$ at $1645 \mathrm{EST}$ with the higher $\mathrm{O}_{3}$ measured by the ship on the water surface. Ozone gradients exist both vertically over the bay and horizontally from the land to the water. Both of these are caused by the aforementioned shallow stable layers formed over water, trapping surface $\mathrm{O}_{3}$. The horizontal and vertical gradients in $\mathrm{O}_{3}$ and shallow, weak layers of stability over the Chesapeake Bay water surface call for additional soundings and chemical measurements over water in this region in the future.

\subsection{Temporal and spatial evolution of bay breeze $\mathrm{O}_{3}$}

A case-study comparison of 2 days, one with a bay breeze (05 July) and one without (20 July), both of which violated the EPA 8-h standard for $\mathrm{O}_{3}$, is shown in Fig. 5. Tethered balloon profiles at Eagle Point illustrate the time-evolution of $\mathrm{O}_{3}$ structures and vertical stability as influenced by the Chesapeake Bay. Profiles for each day were taken at comparable times and differences in both stability and $\mathrm{O}_{3}$ are observed as a function of time. The bay breeze passage occurred at approximately 1100 EST on 05 July. Ozone increases over time with each profile on bay breeze days such as 05 July with the advection of $\mathrm{O}_{3}$-rich air from the bay. Surface $\mathrm{O}_{3}$ peaks with highest photochemical production in the early afternoon on non-bay breeze days, then levels or decreases in the evening hours whereas $\mathrm{O}_{3}$ mixing ratios are continuously increasing, likely through advection on bay breeze days. The heating of the lowest levels occurs more quickly on 20 July, which can assist vertical mixing and dilution of $\mathrm{O}_{3}$, whereas the bay breeze acts to moderate daytime heating on 05 July. Evidence of a TIBL can be seen in the last profile shown for 05 July as a shallow layer of higher stability and higher $\mathrm{O}_{3}$ mixing ratios are seen in the lowest $150 \mathrm{~m}$.

Further effects of complex near-surface layers and a TIBL are found in an ozonesonde sounding following the bay breeze frontal passage at Edgewood on 22 July (Fig. 6). This sounding is compared with a relatively clean and well mixed profile from $14 \mathrm{July}$. The layers of stability and comparably high $\mathrm{O}_{3}$ on 22 July can be seen close to the surface within the low mixing height of the TIBL (marked at $400 \mathrm{~m}$ by BLH method 4) as the air mass is advected onshore by the bay breeze. The 14 July vertical profiles are much more uniform with respect to $\theta_{v}$ and $\mathrm{O}_{3}$, as expected in a well-mixed PBL. This mixing alleviates the buildup of $\mathrm{O}_{3}$ at the surface. While the Heffter (1980) BLH method picks a reasonable location for the top of the boundary layer on 14 July $(2.1 \mathrm{~km})$, its calculation of BLH on 22 July $(2.5 \mathrm{~km})$ shows its shortcomings at times when distinct layers exist. This layering of stability and high $\mathrm{O}_{3}$ again gives evidence that the TIBL confounds the vertical distribution of $\mathrm{O}_{3}$ on bay breeze days.

Surface $\mathrm{O}_{3}$ measurements at Edgewood are compared to five nearby MDE stations (Aldino, Beltsville, Essex, Fair Hill, and Padonia) for 05 July in Fig. 7. The bay breeze initiated at Edgewood at 1100 EST and contributed to a violation of the EPA standard at Edgewood and Essex, the latter being another location susceptible to bay breeze effects not fully studied here. Figure 7 highlights the magnitude of the effect a bay breeze can have on surface $\mathrm{O}_{3}$ as well as the horizontal variability it induces between the six studied DISCOVER-AQ locations. Figure 8 shows the entire month of average hourly $\mathrm{O}_{3}$ differences amongst Edgewood and the five other MDE sites for July 2011. On bay breeze and "interrupted" days, Edgewood consistently displayed hourly $\mathrm{O}_{3}$ much higher than the average hourly $\mathrm{O}_{3}$ of the other five MDE sites. On non-bay breeze days in Fig. 8 the 


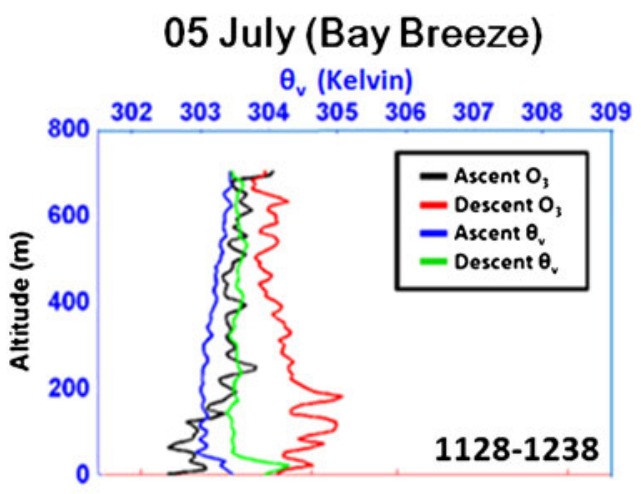

20 July (No Bay Breeze)
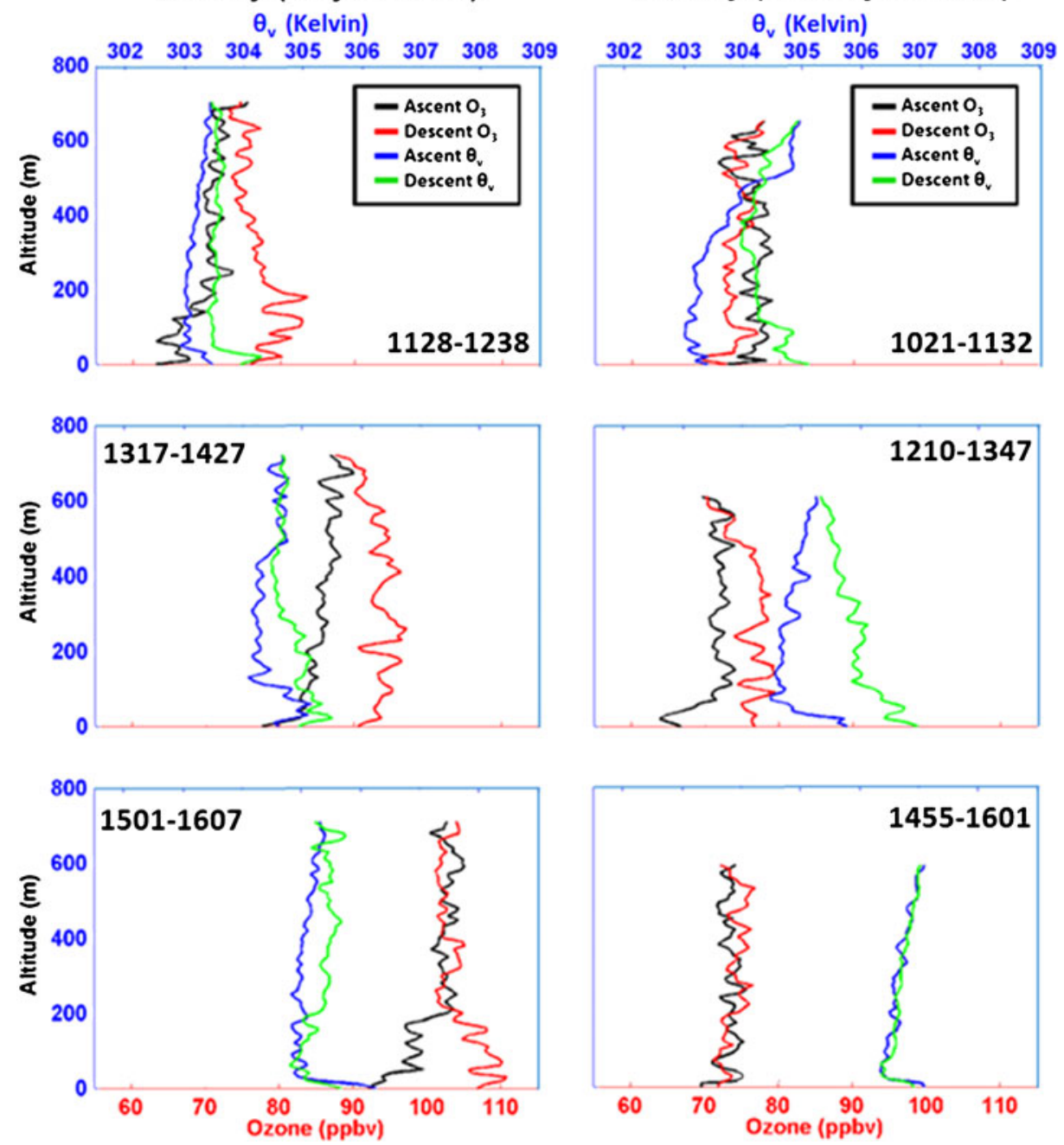

Fig. 5 Eagle Point tethered balloon flights on 05 July (bay breeze) and 20 July (no bay breeze) showing progression of $\mathrm{O}_{3}$ (ascent: black, descent: $r e d$ ) and virtual potential temperature (ascent: blue, descent: green) on two exceedance days. Flight times in EST are labeled on each profile and data are bin-averaged every $10 \mathrm{~m}$. Chesapeake Bay effects are observed with a stable layer containing high $\mathrm{O}_{3}$ in the lowest $200 \mathrm{~m}$ of the last profile on 05 July

differences amongst the locations are much less. When considering the 8 -h averaged $\mathrm{O}_{3}$, these values were statistically the same on non-bay breeze days amongst the six DISCOVER-AQ sites with an average difference of 0.3 ppbv $\mathrm{O}_{3}$ between Edgewood and the five other sites. This difference jumps to $10.8 \mathrm{ppbv}$ on bay breeze and "interrupted" days and is statistically different from non-bay breeze days with $95 \%$ confidence. These analyses show how Edgewood consistently observes higher afternoon surface $\mathrm{O}_{3}$ than nearby locations during bay breeze events. It has been described how large-scale meteorological conditions favorable for bay breeze initiation are also conducive to surface $\mathrm{O}_{3}$ production, but the areas directly affected by the recirculation of chemically aged air in the bay breeze 

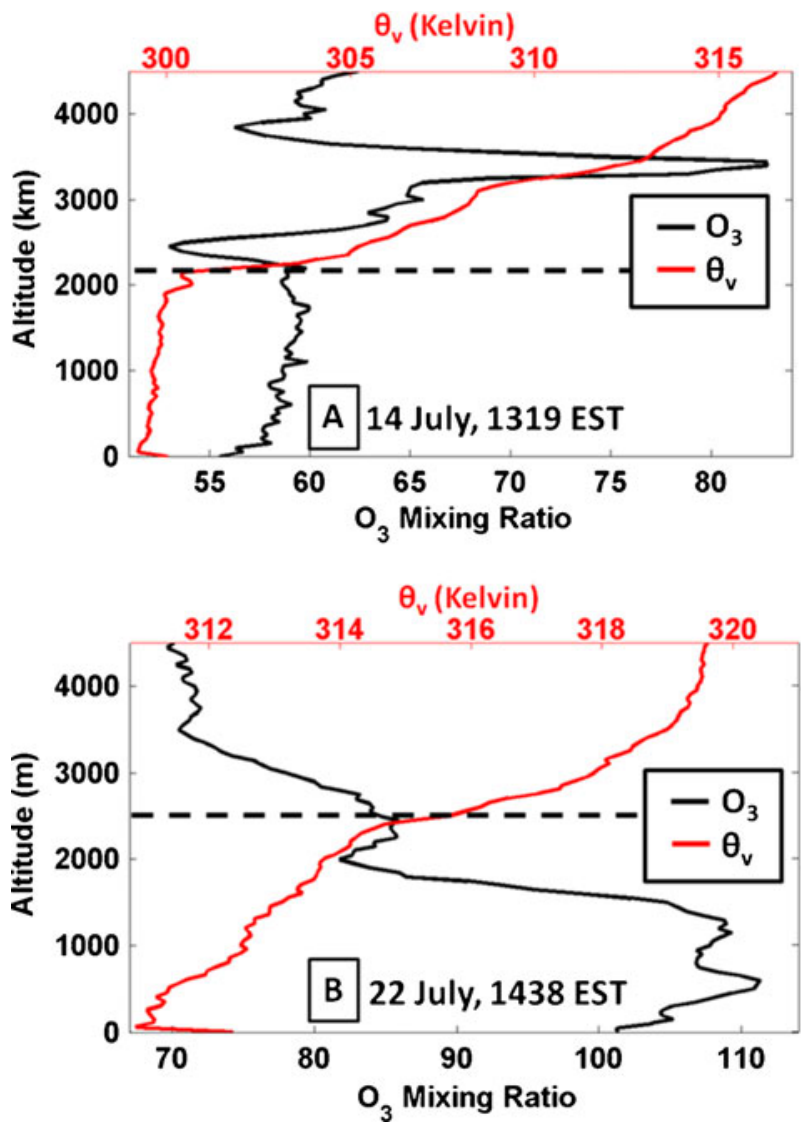

Fig. 6 Surface to $4.5 \mathrm{~km}$ profiles of $\mathrm{O}_{3}$ (black) and virtual potential temperature (red) from two ozonesonde flights on 14 July (a) and 22 July (b). 22 July was an "interrupted" day with the bay breeze regaining strength in the afternoon and evening hours after a midday thunderstorm. Horizontal dashed lines mark the estimated tops of the boundary layer using the Heffter (1980) method. Launch times are noted on each profile and data are bin-averaged every $50 \mathrm{~m}$

Fig. 7 Hourly surface $\mathrm{O}_{3}$ at six DISCOVER-AQ stations on 05 July. The initiation of the bay breeze at Edgewood is shown as the vertical dashed line, occurring around 1100 EST

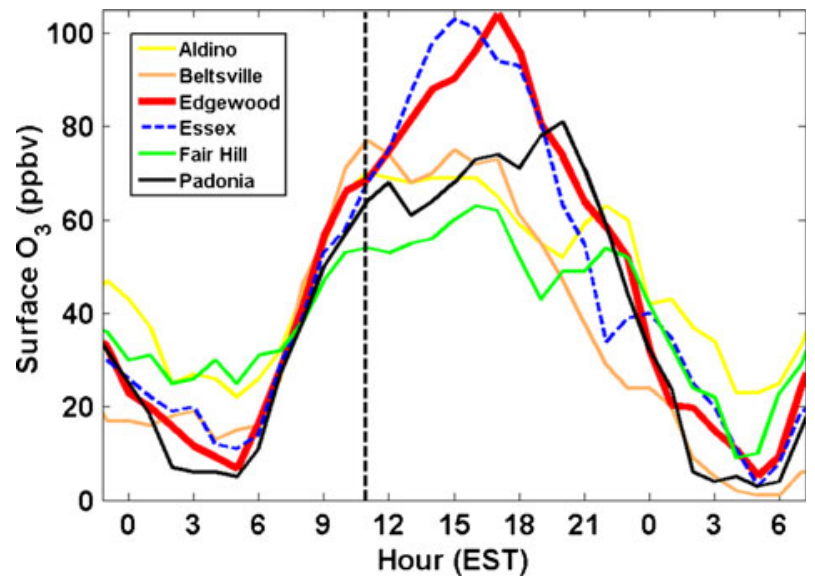


Fig. $81-\mathrm{h} \mathrm{O}_{3}$ difference between Edgewood and the average of five nearby $\mathrm{MDE}_{3}$ sites for bay breeze days (orange and red), "interrupted" days (cyan and blue), and non-bay breeze days (grey and black). AM is defined as 0100-1200 EST and PM is defined as 1300-2400 EST

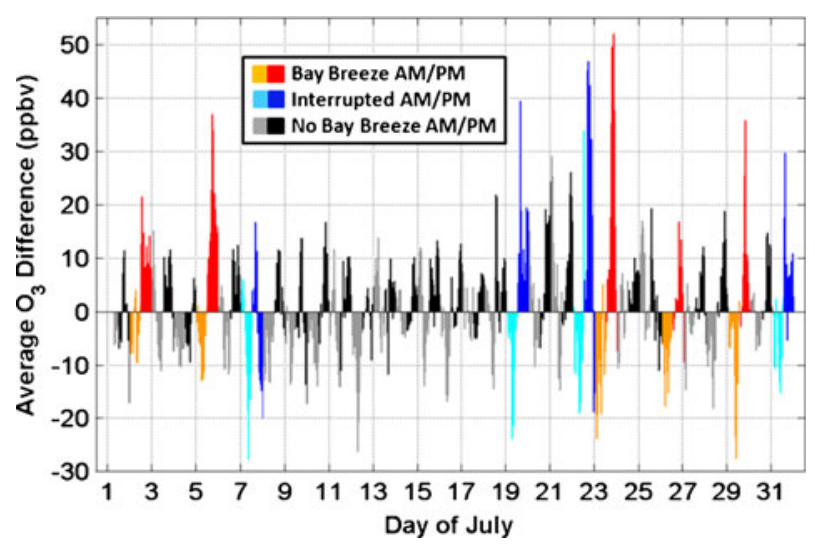

observe $\mathrm{O}_{3}$ mixing ratios higher than regional mixing ratios. This localized, elevated $\mathrm{O}_{3}$ drives exceedances in this region, and is often the cause of comparably poor air quality at Edgewood.

Bay breeze impacts are also apparent on scales much smaller than the inter-site distance. 29 July was identified as a bay breeze day at NATIVE, with the frontal passage characterized by the bay breeze criteria at NATIVE (and Eagle Point) occurring around 1530 EST. Evidence shows that Eagle Point was also impacted by the stable, high $\mathrm{O}_{3}$ bay breeze air mass several hours earlier around 1230 EST (Fig. 9). A spike in $\mathrm{O}_{3}$ was accompanied by a brief wind shift from northerly to southerly, a $2{ }^{\circ} \mathrm{C}$ drop in temperature, and a $3 \mathrm{~g} \mathrm{~kg}^{-1}$ rise in specific humidity in $30 \mathrm{~min}$ at the surface at Eagle Point. The very shallow $(<100 \mathrm{~m})$ layer in which the effects of the Chesapeake air mass are seen in Fig. 9 demonstrates how $\mathrm{O}_{3}$ can be concentrated in the TIBL at the immediate coast (Eagle Point is less than $500 \mathrm{~m}$ west of the water). The cool and moist air mass then moved off the coast as the winds shifted back from the north and humidity, $\mathrm{O}_{3}$ and $\theta_{\mathrm{v}}$ lapse rate returned to previous levels, showcasing the competition between the land/water pressure gradient from thermal contrast and weak synoptic scale forcing from north/northwesterly directions. Coincident measurements at the NATIVE site found no such effect as winds remained light from the north/northwest and $\mathrm{O}_{3}$ mixing ratios held steady. Later in the afternoon the bay breeze re-formed, moving back inland passing through Eagle Point and NATIVE. Scales on which circulations like this exist are evidently relevant, and motivate the need for high-resolution meteorological and chemical modeling validation from July 2011 .

\section{Conclusions}

The bay breeze has a profound impact on surface $\mathrm{O}_{3}$ mixing ratios at Edgewood. The bay breeze consistently contributed to exceedances of the 75 ppbv NAAQS value at Edgewood during July 2011. Eight of the 9 days in which a bay breeze or interrupted bay breeze event was observed at Edgewood exceeded this standard, and the only two Code Red days occurred on bay breeze/"interrupted" days. The bay breeze day that did not exceed the EPA standard fell 1 ppbv short at $74 \mathrm{ppbv}$. The continuous advection of $\mathrm{O}_{3}$ late into the evening toward sunset has implications for the risk of extended exposure to the population. Ozone was found to peak an average of $3 \mathrm{~h}$ later when the bay breeze was sustained all day 


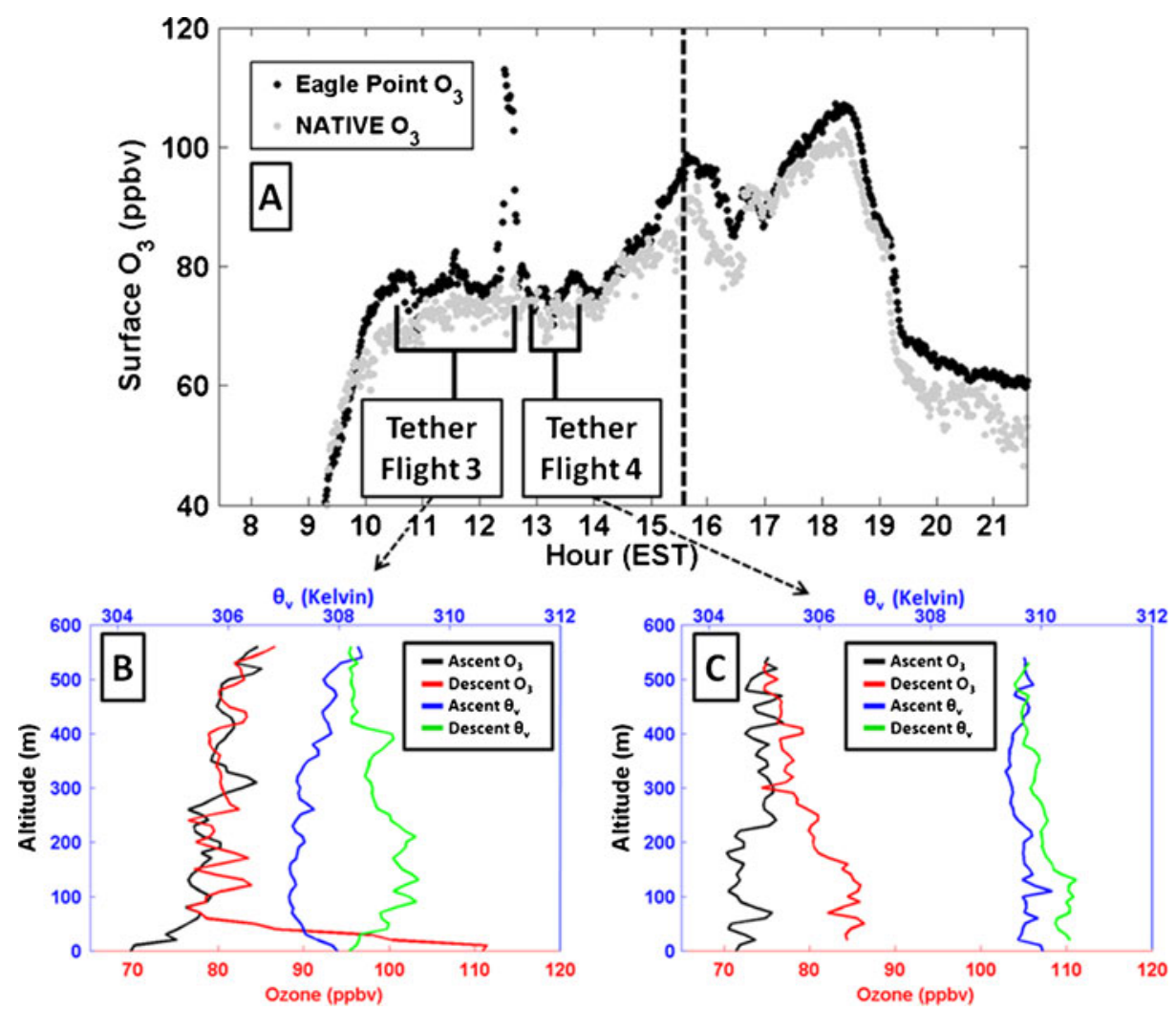

Fig. 9 Surface $\mathrm{O}_{3}$ at Eagle Point (black, a) and NATIVE (grey, a), for 29 July with corresponding Eagle Point tethered balloon flights (b, c, color scheme same as in Fig. 5) marked by launch start and end. The bay influence is seen in the spike in Eagle Point surface $\mathrm{O}_{3}$ as well as the stable surface layer and higher $\mathrm{O}_{3}$ in the lowest $100 \mathrm{~m}$ at the end of tethered balloon flight 3 (b). Bay breeze initiation at NATIVE is marked by the vertical black dashed line. Tether profile data are bin-averaged every $10 \mathrm{~m}$

than other days in July 2011. The maximization of $\mathrm{O}_{3}$ well past the hours of highest incoming solar radiation around solar noon gives evidence that bay breeze transport is a dominant process at Edgewood, more so than at other sites. This phenomenon appears to play a defining role in Edgewood's poor air quality relative to other $\mathrm{O}_{3}$ monitors in the Baltimore NAA.

The observation of land/water horizontal and vertical gradients of $\mathrm{O}_{3}$ over the Chesapeake Bay on four separate days during DISCOVER-AQ 2011 point to a need for more consistent monitoring of air quality over the Chesapeake Bay waters, allowing more statistically stringent analyses to determine if the existence of higher $\mathrm{O}_{3}$ mixing ratios over the Chesapeake is commonplace during the summer months. Land-water $\mathrm{O}_{3}$ gradients and inhibited vertical mixing over cooler water surfaces are key components of the bay breeze/ coastal air quality dynamic.

The bay breeze front often acts as a boundary between terrestrial air masses and $\mathrm{O}_{3}$-rich air masses existing over the bay. The event at Eagle Point on 29 July is a good example of such a case. Prior to the development of computer resources sufficient to run models on a high enough resolution to capture the scales on which bay breezes occur, derived indices were relied upon to predict the potential for bay or water-body breezes (Biggs and Graves 
1962; Laird et al. 2001; Sikora et al. 2010). The complex coastline and warm (relative to large bodies of water) waters of the Chesapeake Bay make predicting these important small-scale circulations difficult and require fine-scale meteorological modeling for resolution of the bay breeze. This work also expressed the importance of vertical stability over the bay and over land during bay breezes, which has a strong effect on the vertical and horizontal distribution of $\mathrm{O}_{3}$. Thus, accurately modeling boundary layer heights in this region is also paramount. In-depth investigations into chemical and meteorological modeling results from DISCOVER-AQ 2011 will be pursued in future research.

A long term study into the potential differences in total and tropospheric column $\mathrm{O}_{3}$ should be performed to find statistical differences between bay breeze and non-bay breeze days using either satellite overpass data from the Ozone Monitoring Instrument (OMI) on board the Aura satellite or the continuous ground-based measurements provided by the Pandora instrument (Herman et al. 2009; Tzortziou et al. 2012). Analyses of column trace gases of $\mathrm{O}_{3}$ and $\mathrm{NO}_{2}$ during DISCOVER-AQ in support of the upcoming NASA Geo-CAPE mission will also be the focus of future research.

Acknowledgments Funding and research for this project was provided by the NASA DISCOVER-AQ grant NNX10AR39G as well as NASA grant NNX08AJ15G. The authors would like to thank James Crawford, Mary Kleb, Kenneth Pickering, Gao Chen and all the DISCOVER-AQ participants for their support and contributions. Thanks also to Lacey Brent for ship and aircraft measurements with additional support from MDE, and NIST for calibration assistance. Thanks to Andrew Weinheimer (NCAR), Edwin Gluth, Laura Warren, Jennifer Hains, Mike Woodman and Dave Krask (MDE), and Hannah Halliday, Greg Garner, Andra Reed, Debra Kollonige (PSU) for their assistance and Bill Ryan (PSU) for his early insights into the potential for bay breeze effects on ozone.

Open Access This article is distributed under the terms of the Creative Commons Attribution License which permits any use, distribution, and reproduction in any medium, provided the original author(s) and the source are credited.

\section{References}

Angevine, W.M., Senff, C.J., White, A.B., Williams, E.J., Koermer, J., Miller, S.T.K., Talbot, R., Johnston, P.E., McKeen, S.A., Downs, T.: Coastal boundary layer influence on pollutant transport in New England. J. Appl. Meteorol. 43, 1425-1437 (2004)

Banta, R.M., Senff, C.J., Nielsen-Gammon, J., Darby, L.S., Ryerson, T.B., Alvarez, R.J., Sandberg, S.P., Williams, E.J., Trainer, M.: A bad air day in Houston. Bull. of the Am. Meteorol. Soc. May 2005, 657669 (2005). doi:10.1175/BAMS-86-5-657

Banta, R.M., Senff, C.J., Alvarez, R.J., Langford, A.O., Parrish, D.D., Trainer, M.K., Darby, L.S., Hardesty, R.M., Lambeth, B., Neuman, J.A., Angevine, W.M., Nielsen-Gammon, J., Sandberg, S.P., White, A.B.: Dependence of daily peak $\mathrm{O}_{3}$ concentrations near Houston, Texas on environmental factors: Wind speed, temperature, and boundary-layer depth. Atmos. Environ. 45, 162-173 (2011). doi:10.1016/ j.atmosenv.2010.09.030

Berman, S., Ku, J.-Y., Rao, S.-T.: Spatial and temporal variation in the mixing depth over the northeastern United States during the summer of 1995. J. Appl. Meteorol. 38, 1661-1673 (1999)

Biggs, W.G., Graves, M.E.: A lake breeze index. J. Appl. Meteorol. 1, 474-480 (1962)

Bloomer, B.J., Stehr, J.W., Piety, C.A., Salawitch, R.J., Dickerson, R.R.: Observed relationships of ozone air pollution with temperature and emissions. Geophys. Res. Lett. 36, L09803 (2009). doi:10.1029/ 2009GL037308

Brooks, I.M.: Finding boundary layer top: application of a wavelet covariance transform to lidar backscatter profiles. J. Atmos. Ocean. Technol. 20, 1092-1105 (2003)

Burnett, R.T., Dales, R.E., Raizenne, M.E., Krewski, D., Summers, P.W., Roberts, G.R., Raad-Young, M., Dann, T., Brook, J.: Effects of low ambient levels of ozone and sulfates on the frequency of respiratory admissions to Ontario hospitals. Environ. Res. 65, 172-194 (1994) 
Comrie, A.C.: The climatology of surface ozone in rural areas: A conceptual model. Prog. Phys. Geogr. 14, 295 (1990). doi:10.1177/030913339001400301

Darby, L.S.: Cluster analysis of surface winds in Houston, Texas, and the impact of wind patterns on ozone. J. Appl. Meteorol. 44, 1788-1806 (2005)

Darby, L.S., McKeen, S.A., Senff, C.J., White, A.B., Banta, R.M., Post, M.J., Brewer, W.A., Marchbanks, R., Alvarez II, R.J., Peckham, S.E., Mao, H., Talbot, R.: Ozone differences between near-coastal and offshore sites in New England: Role of meteorology. J. Geophys. Res. 112, D16S91 (2007). doi:10.1029/ 2007JD008446

Davis, K.J., Gamage, N., Hagelberg, C.R., Kiemle, C., Lenschow, D.H., Sullivan, P.P.: An objective method for deriving atmospheric structure from airborne lidar observations. J. Atmos. Ocean. Technol. 17, 14551468 (2000)

Ding, A., Wang, T., Zhao, M., Wang, T., Li, Z.: Simulation of sea-land breezes and a discussion of their implications on the transport of air pollution during a multi-day ozone episode in the Pearl River Delta of China. Atmos. Environ. 39, 6737-6750 (2004)

Efron, B.: Bootstrap methods: Another look at the jackknife, 1979, The Annals of Statistics, 7 (1), http:// www.jstor.org/stable/2958830. Accessed April 202012

Efron, B., Tibshirani, R.J.: An Introduction to the bootstrap. Chapman and Hall, Boca Raton (1993)

Environmental Protection Agency: National Ambient Air Quality Standards, http:/www.epa.gov/air/criteria.html. Accessed 25 April 2012

Fry, D.: Aberdeen Proving Ground: Maryland's Newest Economic Powerhouse, Center Maryland, http:// articles.centermaryland.org/?p=3509. Accessed 20 April 2012

Gangoiti, G., Alonso, L., Navazo, M., Albizuri, A., Perez-Landa, G., Matabuena, M., Valdenebro, V., Maruri, M., Garcia, J.A., Millan, M.M.: Regional transport of pollutants over the Bay of Biscay: analysis of an ozone episode under a blocking anticyclone in west-central Europe. Atmos. Environ. 36, 1349-1361 (2002)

Hauglustaine, D.A., Granier, C., Brasseur, G.P., Mégie, G.: The importance of atmospheric chemistry in the calculation of radiative forcing on the climate system. J. Geophys. Res. 99(D1), 1173-1186 (1994). doi:10.1029/93JD02987

Heffter, J.L.: 1980, Air resources laboratories atmospheric transport and dispersion model, NOAA Tech. Memo., ERL ARL-81, pp. 24 (1980)

Herman, J., Cede, A., Spinei, E., Mount, G., Tzortziou, M., Abuhassan, N.: $\mathrm{NO}_{2}$ column amounts from ground-based Pandora and MFDOAS spectrometers using the direct-sun DOAS technique: Intercomparisons and application to OMI validation. J. Geophys. Res. 114, D13307 (2009). doi:10.1029/ 2009JD011848

Hsu, S.A., Blanchard, B.W.: Recent advances in air-sea interaction studies applied to overwater air quality modeling: A review. Pure Appl. Geophys. 160, 297-316 (2003)

Jerrett, M., Burnett, R.T., Pope III, C.A., Ito, K., Thurston, G., Krewski, D., Shi, Y., Calle, E., Thun, M.: Longterm ozone exposure and mortality. The New England J. of Med. 360, 1085-1095 (2009)

Komhyr, W.D.: Electrochemical concentration cells for gas analysis. Ann. Geophys. 25, 203-210 (1969)

Krupa, S.V., Manning, W.J.: Atmospheric ozone: Formation and effects on vegetation. Environ. Pollut. 50, 101-137 (1988)

Laird, N.F., Kristovich, D.A.R., Liang, X.-Z., Arritt, R.W., Labas, K.: Lake Michigan lake breezes: Climatology, local forcing, and synoptic environment. J. Appl. Meteorol. 40, 409-424 (2001)

Landry, L.: The influence of the Chesapeake Bay breeze on Maryland air quality, MARAMA Data Analysis Workshop, 20 Jan. 2011

Lenschow, D.H., Pearson Jr., R., Stankov, B.B.: Estimating the ozone budget in the boundary layer by use of aircraft measurements of ozone eddy flux and mean concentration. J. Geophys. Res. 86(C8), 7291-7297 (1981). doi:10.1029/JC086iC08p07291

Lenschow, D.H., Pearson Jr., R., Stankov, B.B.: Measurements of ozone vertical flux to ocean and forest. J. Geophys. Res. 87(C11), 8833-8837 (1982). doi:10.1029/JC087iC11p08833

Loughner, C.P., Allen, D.J., Pickering, K.E., Zhang, D.-L., Shou, Y.-X., Dickerson, R.R.: Impact of fairweather cumulus clouds and the Chesapeake Bay breeze on pollutant transport and transformation. Atmos. Environ. 45, 4060-4072 (2011)

Martins, D.K., Stauffer, R., Thompson, A.M., Pippin, M., Knepp, T.: Surface ozone at a coastal suburban site in 2009 and 2010: Relationships to chemical and meteorological processes. J. Geophys. Res. 117, D05306 (2012). doi:10.1029/2011JD016828

Maryland Department of the Environment: Redesignation request for Kent and Queen Anne's Counties 8-hour ozone nonattainment area, http:/www.mde.state.md.us/assets/document/KQA-Redesignation-8hrOzone.pdf. Accessed 23 May 2012

Miller, S.T.K., Keim, B.D., Talbot, R.W., Mao, H.: Sea breeze: Structure, forecasting, and impacts. Rev. Geophys. 41(3), 1011 (2003). doi:10.1029/2003RG000124 
National Weather Service Hydrometeorological Prediction Center: HPC's Surface Analysis Archive, http:// www.hpc.ncep.noaa.gov/html/sfc_archive.shtml. Accessed 15 October 2011

Piety, C.: Appendix G-11: The role of land-sea interactions on ozone concentrations at the Edgewood, Maryland monitoring site, WOE Ch. 6 (2007)

Rappenglück, B., Perna, R., Zhong, S., Morris, G.A.: An analysis of the atmosphere and the upper level meteorology and their impact on surface ozone levels in Houston, Texas. J. Geophys. Res. 113, D17315 (2008). doi:10.1029/2007JD009745

Raynor, G.S., Sethuraman, S., Brown, R.M.: Formation and characteristics of coastal internal boundary layers during onshore flows. Bound. Layer Meteorol. 16, 487-514 (1979)

Sikora, T.D., Young, G.S., Bettwy, M.J.: Analysis of the western shore Chesapeake Bay bay-breeze. Natl. Weather Dig. 34, 55-65 (2010)

Sillman, S., Samson, P.J.: Impact of temperature on oxidant photochemistry in urban, polluted rural and remote environments. J. Geophys. Res. 100(D6), 11497-11508 (1995). doi:10.1029/94JD02146

Steiner, A.L., Davis, A.J., Sillman, S., Owen, R.C., Michalak, A.M., Fiore, A.M.: Observed suppression of ozone formation at extremely high temperatures due to chemical and biophysical feedbacks. Proc. Natl. Acad. Sci. (2010). doi:10.1073/pnas.1008336107

Tzortziou, M., Herman, J.R., Cede, A., Abuhassan, N.: High precision, absolute total column ozone measurements from the Pandora spectrometer system: Comparisons with data from a Brewer double monochromator and Aura OMI. J. Geophys. Res. 117, D16303 (2012). doi:10.1029/2012JD017814

Wang, T., Wu, Y.Y., Cheung, T.F., Lam, K.S.: A study of surface ozone and the relation to complex wind flow in Hong Kong. Atmos. Environ. 35, 3203-3215 (2001)

Wesely, M.L., Hicks, B.B.: A review of the current status of knowledge on dry deposition. Atmos. Environ. 34, 2261-2282 (2000)

Wu, Y.-L., Lin, C.-H., Lai, C.-H., Lai, H.-C., Young, C.-Y.: Effects of local circulations, turbulent internal boundary layers, and elevated industrial plumes on coastal ozone pollution in the downwind Kaohsiung urban-industrial complex. Terr., Atmos. and Ocean Sci. 21(2), 343-357 (2010)

Zhang, F., Bei, N., Nielsen-Gammon, J.W., Li, G., Zhang, R., Stuart, A., Aksoy, A.: Impacts of meteorological uncertainties on ozone pollution predictability estimated through meteorological and photochemical ensemble forecasts. J. Geophys. Res. 112, D04304 (2007). doi:10.1029/2006JD007429 